\title{
Cerebral Palsy Patient who undergone Coronary Artery Bypass Grafting with Mitral Valve Replacement
}

Taner İyigün' ${ }^{1}$, Mugisha Kyaruzi ${ }^{1}$, Ali Tabakan ${ }^{1}$, Başol Bay ${ }^{2}$ and Mehmet Kaya ${ }^{1}$

${ }^{1}$ Department of Cardiovascular Surgery, Istanbul Mehmet Akif Ersoy Thoracic and Cardiovascular Surgery Training and Research Hospital, Turkey ${ }^{2}$ Department of Cardiac anesthesiology, Istanbul Mehmet Akif Ersoy Thoracic and Cardiovascular Surgery Training and Research Hospital, Turkey Submission: December 12, 2017; Published: January 11, 2018

*Corresponding author: Taner İyigün, Department of Cardiovascular Surgery, Istanbul Mehmet Akif Ersoy Thoracic and Cardiovascular Surgery Training and Research Hospital, Istanbul, Turkey, Tel: +905302003422; Email: taneriyi@gmail.com

\begin{abstract}
We are reporting on 57 years old man suffering from cerebral palsy who undergone coronary artery bypass grafting (CABG) in concomitant with mitral valve replacement (MVR). Due to multiple articular contractures entubation difficulties, grafts availability and posture difficulties are challenging matters during surgery. We describe our planning that lead to a successiful mitral valve replacement in concomitant with coronary artery bypass grafting surgery in this peculiar situation.
\end{abstract}

Keywords: Cerebral palsy; Tracheostomy; Cardiac surgery

\section{Introduction}

Cerebral palsy is a disease associted with abnormality of motor function that appears in an early age [1]. It is a nonprogressive condition, but the involvement of extremities often develops articular contracture and abnormal posture. Its association with coronary artery bypass grafting (CABG) presents technical issues during surgery. These includes choice of grafts, positioning and the approach of intubation. We report on an adult patient with cerebral palsy who undergone CABG, mitral valve replacement and describe our perioperative planning.

\section{Case Report}

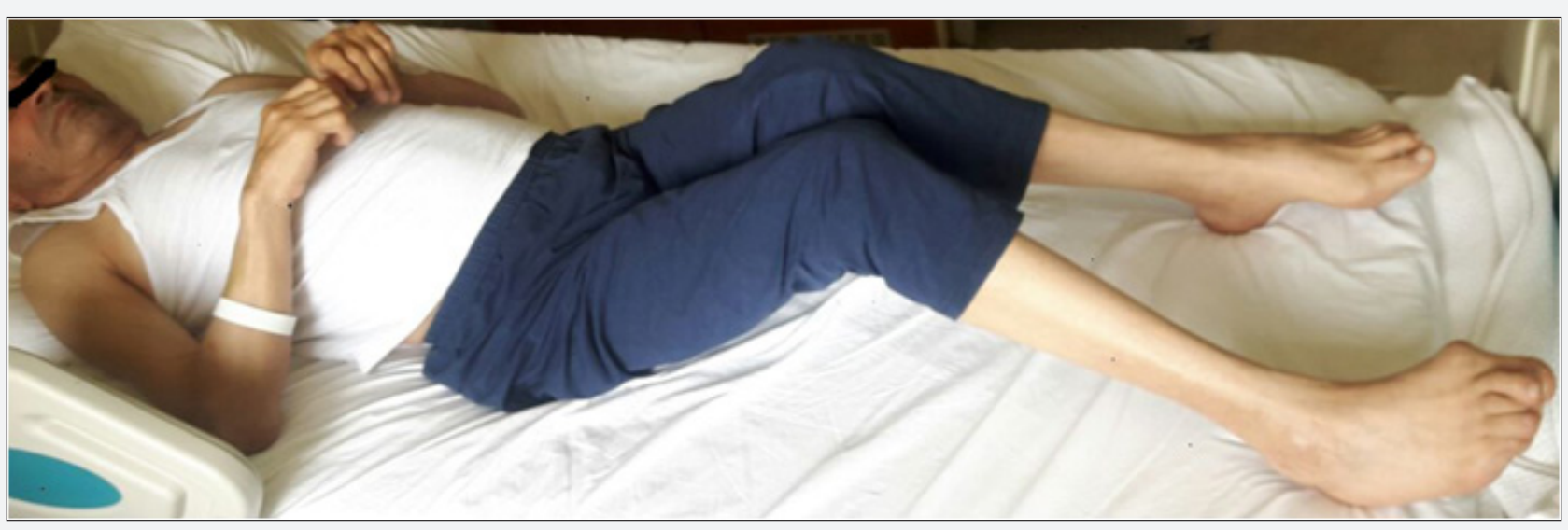

Figure 1: Preoperative photo showing the posture position of our patient. 


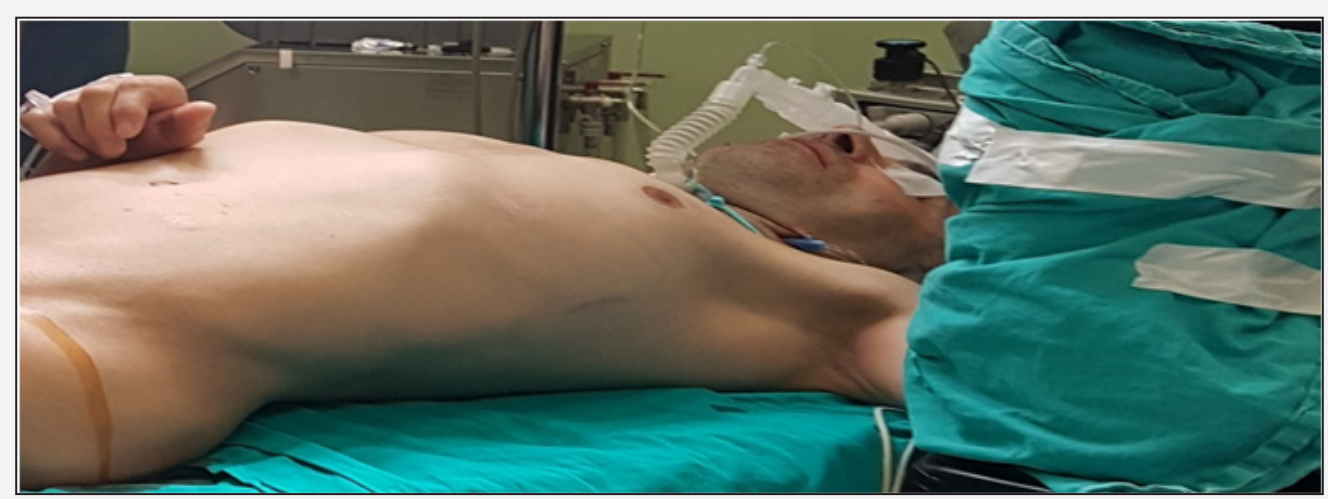

Figure 2 : Preoperative photo showing positioning of our patient with tracheotomy.

A 76-year-old man with chest pain and fatigue was presented to our hospital cardiology department. Electrocardiography showed no changes. Echocardiography findings revealed a normal ejection fraction of $60 \%$ with moderate romatizmal mitral valve stenosis. Coronary angiography was perfomed through the right radial artery. Coronary angiography revealed critical Coronary lesions in both three main vessels (LAD 90\% distal, CX 70\% midportion, OM 1\% 80 lesion, RCA\% subtotal occlusion). This patient was suffering from cerebral palsy that had affected all four limbs and neck described as pentaplegia. The hip joints were contracted in adducts and flexion position, and the knees were fixed in flexion, presenting both knees pulled up on a supine position (Figure 1).

The abduction of shoulder joints was tightly restricted, but the involvement of forearms and hands was mild; therefore he was able to take care of his matters using the upper limbs.The neck was tightly fixed on flexion. This patient was classified as pentaplegia, and his intelligence appeared to be normal. We planned an urgent CABG with MVR, in which the positioning a patient for sugery was difficult with left arm positioned in upright position and right arm on the abdomen position (Figure 2), harvesting of saphenous vein grafts was technically difficult (only one saphenous graft was harvested), entubation was not possible through mouth-lung entubation whereby emergency tracheostomy was perfomed. Left internal thoracic artery (LITA) was harvested in skeletonized fashion. He was discharged from hospital uneventfully.

\section{Discussion}

Cerebral palsy patients are able to lead a nearly normal life when their neurological problems are properly managed. Ischemic heart diseases may develop during their adulthood . To the best of our knowledge, this case is the first report of cardiac surgery of coronary arteries and mitral valve replacement in an adult with cerebral palsy. Open cardiac surgery in this situation presents several technical issues related to severe contractures of the extremities. One is availability of grafts, both the radial artery and saphenous vein, harvested from extremities. Our patient's saphenous vein graft was harvested in his normal body posture. LITA was good to harvest, but a "hybrid" revascularization may be required in case of grafts shortage [2].

The other difficulty is entubation in which endotracheal intubation failure tracheostomy may be required. Tracheostomy is a safer and more comfortable way for mechanical ventilation and is indicated in such cases of prolonged ventilation [1]. Tracheostomy may be perfomed percutaneously or surgically [4]. In our case normal intubation was not possible that lead to emergency percutaneous tracheostomy for respiratory management. Moreover tracheostomy removal should be done when all morbidites assocciated with cardiac surgery are not likely to occur.

\section{Conclusion}

In conclusion, we reported on a patient with cerebral palsy who survived CABG and MVR. Our planning was successful in managing this serious condition.

\section{References}

1. Huttenlocher PR (1987) Nelson Textbook of Pediatrics. In: Behrman RE \& Vaughan VC III (Eds.), Cerebral palsy. WB Saunders, Philadelphia, USA, pp. 1307-1309.

2. Kurisu K, Hisahara M, Ando Y (2007) Coronary artery bypass grafting in cerebralpalsy with severe contractures of extremities. Ann Thorac Cardiovasc Surg 13(6): 421-422.

3. Ben-Avi R, Ben-Nun A, Levin S, Simansky D, Zeitlin N, et al. (2014) Tracheostomy after cardiac surgery: timing of tracheostomy as a risk factor for mortality, J Cardiothorac Vasc Anesth 28(3): 493-496.

4. Briggs S, Ambler J, Smith D (2007) A survey of tracheostomy practice in a cardiothoracic intensive care unit. J Cardiothorac Vasc Anesth 21(1): 76-80. 
This work is licensed under Creative Commons Attribution 4.0 Licens DOI: 10.19080/OAJS.2018.07.555714

\section{Your next submission with Juniper Publishers} will reach you the below assets

- Quality Editorial service

- Swift Peer Review

- Reprints availability

- E-prints Service

- Manuscript Podcast for convenient understanding

- Global attainment for your research

- Manuscript accessibility in different formats

( Pdf, E-pub, Full Text, Audio)

- Unceasing customer service

Track the below URL for one-step submission https://juniperpublishers.com/online-submission.php 